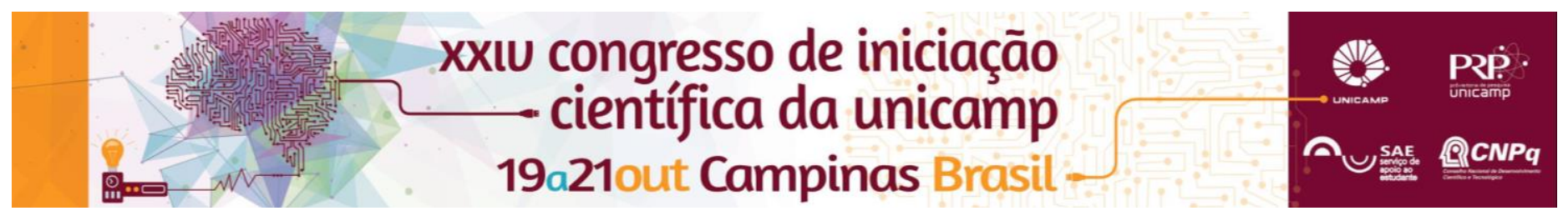

\title{
Análise da qualidade de algoritmo de computação evolutiva para reordenação de matrizes em Visualização de Informação
}

\section{Pedro K. Roque Júnior*, Celmar Guimarães da Silva}

\section{Resumo}

Reordenação de Matrizes é uma técnica utilizada na área de Visualização de Informação para facilitar o entendimento visual dos dados apresentados na matriz. Consiste na permutação de linhas e/ou colunas de uma matriz, sem perda de dados, visando aproximar colunas ou linhas que tenham conteúdos semelhantes, de modo a evidenciar padrões presentes nos dados. Este trabalho visou implementar e analisar os resultados de um algoritmo de computação evolutiva na reordenação de matrizes de dados, comparando-o com outros algoritmos da literatura.

\section{Palavras-chave:}

Visualização de Informação, Reordenação de matrizes, Algoritmos Genéticos.

\section{Introdução}

A MRA (Matrix Reordering Analyser) (Fig. 1) é uma ferramenta de reordenação de matrizes e comparação de resultados entre diferentes algoritmos de reordenação. Neste trabalho implementou-se o algoritmo de reordenação baseado em Evolução Genética (Niermann, 2005). Nele, colunas e linhas são permutadas usando princípios de Genética (mutação e crossover) e de Evolução (torneios entre individuos, levando o individuo vencedor para a próxima geração). As matrizes (original e decorrentes do algoritmo) são tratadas como indivíduos em um processo evolutivo. As ordens de suas linhas e colunas assumem o papel de genes.

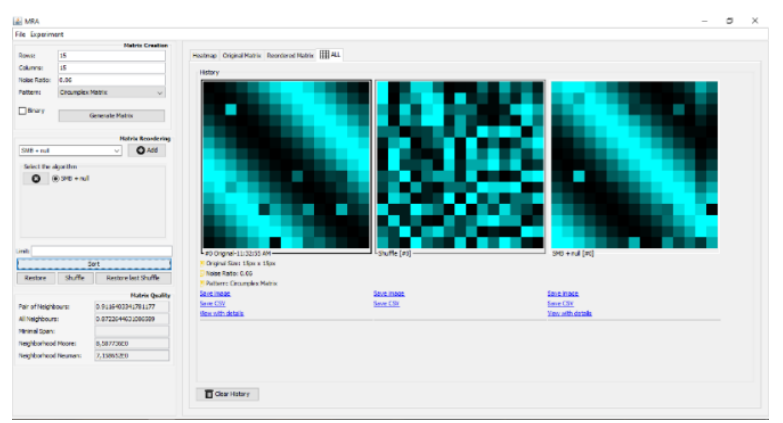

Figura 1. Interface Gráfica da MRA

\section{Resultados e Discussão}

Foram implementados dois operadores para permutação: mutação e crossover. Também foi usado um módulo da MRA para análise da qualidade da matriz; ele informa um valor (stress de Moore) que é utilizado para comparações nos torneios entre indivíduos.

O algoritmo repete 3000 vezes a iteração indicada na Fig. 2. Contudo, decidiu-se neste trabalho condicionar a parada até ser encontrado um individuo com o valor de stress igual ou menor à metade do stress da matriz original. Também se optou por analisar os indivíduos gerados a cada iteração após concluir que se poderia perder um indivíduo de stress baixo no meio do ciclo.

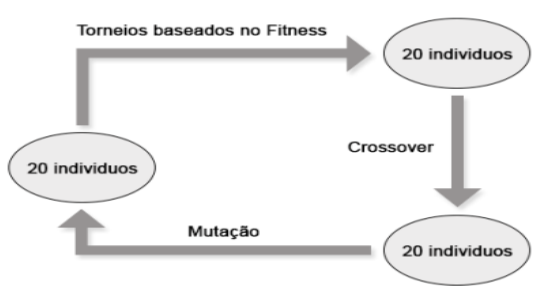

Figura 2. Ciclo do algoritmo.

Para experimentos utilizamos a mesma tabela que Niermann(2005) utilizou em seu experimentos Fig 3. e o resultado que chegamos se encontra na imagem da Fig 4.

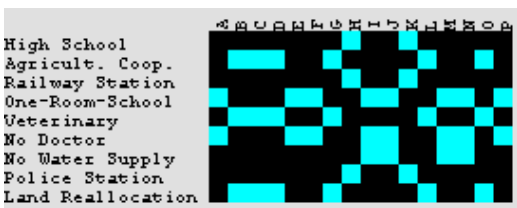

Figura 3. Tabela utilizada por Niermann (Stress: 77,0)

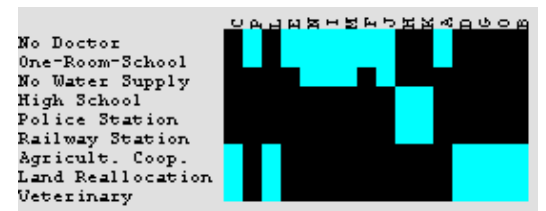

Figura 4. Tabela resultado (Stress: 37,0 )

\section{Conclusões}

Após experimentos chegamos a conclusão que com 0 algoritmo implementado chegamos a valores de estresse ótimos, porém a reordenação e aglomeração de blocos de valores pode não ser tão vantajosas quanto o esperado, pois como tratamos de vários eventos aleatórios o leque de possibilidades é muito alto.

\section{Agradecimentos}

Agradecimentos à $\mathrm{PRP} /$ Unicamp e ao CNPq pelo financiamento deste projeto.

\footnotetext{
${ }^{1}$ NIERMANN, S. Optimizing the Ordering of Tables With Evolutionary Computation, The American Statistician, vol. 59, No 1, p. 41-46, 2005. ${ }^{2}$ SILVA, C.G.; MELO, M.F.; SILVA, F. P.; MEIDANIS, J. PQR sort: using $\mathrm{PQR}$ trees for binary matrix reorganization. Journal of the Brazilian Computer Society 20:3. Springer 2014 .
} 